\title{
PELATIHAN PEMBUATAN WEBSITE MENGGUNAKAN CMS (CONTENT MANAGEMENT SYSTEM) JOOMLA PADA SMK BINA PUTRA MANDIRI
}

\author{
Risah Subariah ${ }^{1^{*}}$ \\ Ghema Nusa Persada ${ }^{2}$ \\ Dede Maulana ${ }^{3}$ \\ Ayu Juwita Sari ${ }^{4}$ \\ Desi Fitriani $^{5}$ \\ Muhammad Wildan Kemal ${ }^{6}$ \\ Syahwafaa Andaruni TTD 7 \\ 1,2,3,4,5,6,7 Universitas Pamulang, Banten, Indonesia \\ dosen02695@unpam.ac.id ${ }^{\left.1^{*}\right)}$ \\ dosen02682@unpam.ac.id ${ }^{2}$
}

Kata Kunci: [Website, CMS, Joomla, Pelatihan, PKM]

\begin{abstract}
Abstrak: Di era digital saat ini, mayoritas orang tidak mengetahui bahwasanya ada alternatif cepat dalam pembuatan website itu sendiri yaitu dengan menggunakan software CMS. CMS itu sendiri mempunya kriteria yang berbeda - beda sesuai dengan kebutuhan user. Contohnya saja dalam pembuatan personal web, user bisa saja menggunakan CMS yang terkenal yaitu CMS Joomla. Joomla sendiri merupakan software CMS yang paling banyak digandrungi dengan lebih dari 40.000 komunitas diseluruh dunia. Namun sayangnya, tidak banyak dari populasi penduduk di dunia yang tidak mengetahui kecanggihan dan keefektifan dari CMS Joomla. Oleh karena yang demikian, diperlukan pengenalan serta training (pelatihan) dalam membangun sebuah website secara praktis berbasis CMS Joomla. Adapun hasil dari PKM ini yaitu memberikan peningkatan pada kreatifitas dan pengetahuan pada siswa dengan memberikan pelatihan pembuatan website menggunakan CMS Joomla.
\end{abstract}

Published by:

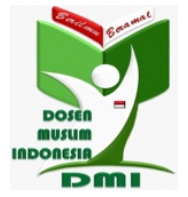

Copyright (C) 2021 The Author(s)

This article is licensed under CC BY 4.0 License (cc) $\mathrm{BY}$ 


\section{Pendahuluan}

Di era Pandemi Covid-19 saat ini, proses metode ajar mayoritas pelajar Indonesia dilaksanakan secara daring. Hal tersebut demikian adanya dikarenakan dampak dari Covid-19 itu sendiri. Covid-19 yang sudah merebak menjadi pandemi memaksa pemerintah dibawah naungan Kementerian Pendidikan dan Kebudayaan untuk selalu memberikan kebijakan - kebijakan yang dijadikan patokan dalam suatu tata Kelola pendidikan di Indonesia. Oleh karenanya hal yang demikian KEMENDIKBUD memperizinkan kepada sekolah yang khususnya berbasis teknik untuk menggunakan metode Luring pada pembelajarannya tanpa melupakan aspek - aspek protocol kesehatan yang ada.

Pengabdian kepada masyarakat adalah bentuk aktualisasi seni budaya, sains, dan teknologi yang dilaksanakan secara langsung kepada masyarakat secara konvensional via metodologi ilmiah sebagai distribusi Tri Dharma Perguruan Tinggi yang bertimbal dengan UU Nomor 20 tahun 2003 Pasal 20:2 mengenai Sistem Pendidikan Nasional yang berisikan bahwasanya Perguruan Tinggi sudah sepatutnya memiliki kewajiban untuk melaksanakan penelitian, pendidikan dan pengabdian kepada masyarakat serta berkewajiban yang luhur dalam ikhtiar mengembangkan kapabilitas di masyarakat. Oleh karenanya dapat memberikan efek cepat pada laju pertumbuhan dan tercapainya destinasi pembangunan nasional.

Di era digital saat ini, pembuatan website sangat diperlukan sebagai media promosi \& aktualiasasi kreatifitas di media masa untuk berbagai macam aktifitas kehidupan, baik pendidikan, sosial, politik, hiburan dan lain sebagainya. Namun terdapat banyak kendala dalam pembuatan website itu sendiri seperti dalam memahami bahasa pemrograman. Bahasa pemrograman menjadi momok tersendiri untuk membuat suatu website di karenakan sulitnya akses untuk mempelajarinya. Pemilihan menggunakan Framework atau CMS menjadi solusi untuk membuat website menjadi responsive dan semakin menarik.

Content Manajement System (CMS) atau dengan nama lain Sistem Manajemen Konten merupakan aplikasi berbasis web yang memiliki sistem sedemikian hingga memberikan kemudahan kepada para pengguna sekaligus pengelolanya (Adhi, R., \& Andy, S. :2006). CMS merupakan sebuah sistem yang memberikan kemudahan kepada para penggunanya dalam mengelola dan mengadakan perubahan isi dalam sebuah website dinamis tanpa dibekali pengetahuan tentang hal-hal yang bersifat teknis sebelumnya.

Sasaran kegiatan PKM ini adalah sebagai wadah perkenalan siswa dengan aplikasi CMS Joomla untuk membuat suatu website sederhana dan praktis serta mengajak siswa SMK Bina Putra Mandiri, untuk ikut aktif mengembangkan kreatifikas dalam pembuatan website praktis ini melalui tema "PELATIHAN PEMBUATAN WEBSITE MENGGUNAKAN CMS (CONTENT MANAGEMENT SYSTEM) JOOMLA PADA SMK BINA PUTRA MANDIRI".

\section{Metode Pelaksanaan}

Metode yang dilakukan pada kegiatan Pengabdian Kepada Masyarakat ini adalah metode presentasi berupa pengenalan dan pelatihan pembuatan website sederhana menggunakan CMS Joomla, sesi Q\&A, serta Quiz yang dilakukan antara panitia dengan 
para peserta PKM, kepada beberapa siswa/siswa SMK Bina Putra Mandiri kelas XI jurusan RPL sejauh mana mereka memahami dan mengerti tentang penggunaan CMS Joomla untuk media interaksi di era tranformasi ini yang sudah mereka pahami. Adapun waktu dan tempat pelaksanaan:

\author{
Hari dan Tanggal : : Sabtu, 03 April 2021 \\ Waktu Pelaksanaan : Pk. 09.00 - 12.00 WIB \\ Tempat Pelaksanaan: SMK Bina Putra Mandiri Jl. Bina Putra Mandiri No.1 \\ Kec Parung Panjang.
}

\title{
Hasil dan Pembahasan
}

Fokus Pengabdian Kepada Masyarakat (PKM) ini yaitu pada kelompok sasaran program pengabdian masyarakat yang meliputi siswa dan siswi SMK Bina Putra Mandiri sejumlah kurang lebih 32 orang. Jumlah 32 orang tersebut merupakan siswa \& siswa SMK Bina Putra Mandiri. Adapun kegiatannya adalah berupa penyuluhan dan pengenalan serta praktek pembuatan website menggunakan CMS Joomla. Pelaksanaan Pengabdian Kepada Masyarakat mengenai Pelatihan Pembuatan Website Menggunakan Cms (Content Management System) Joomla Pada SMK Bina Putra Mandiri dilaksanakan dengan Tahapan Pelaksanaan ( Susunan Acara ). Adapun susunan acara pelaksanaan adalah sebagai berikut:

Tabel 1. Susunan Acara Kegiatan

\begin{tabular}{|c|c|c|c|}
\hline Waktu & Durasi & Acara & Pelaksana \\
\hline $09.00-09.30$ & 30 & Persiapan Bahan PKM & Panitia \\
\hline $09.30-09.40$ & 10 & Pembukaan & Panitia \\
\hline $09.40-09.50$ & 10 & $\begin{array}{l}\text { Sambutan Kepala SMK Bina } \\
\text { Putra Mandiri }\end{array}$ & Ibu Dwi Ratna Ningtyas, M.Kom \\
\hline $09.50-09.55$ & 5 & $\begin{array}{l}\text { Sambutan Perwakilan Dosen } \\
\text { Pendamping PKM }\end{array}$ & Ibu Risah Subariah, M.Kom \\
\hline $09.55-10.00$ & 5 & Sambutan Ketua Pelaksana PKM & Sdr. Dede Maulana \\
\hline $10.00-10.30$ & 30 & Materi Pengenalan CMS Joomla & Narasumber \\
\hline $10.30-11.30$ & 60 & $\begin{array}{l}\text { Praktek Instalasi Pembuatan } \\
\text { Website CMS Joomla }\end{array}$ & Narasumber \& Peserta \\
\hline $11.30-11.40$ & 10 & Question \& Answer & Narasumber \& Peserta \\
\hline $11.40-11.50$ & 10 & Quiz & Narasumber \& Peserta \\
\hline $11.50-12.00$ & 10 & Penutup dan Doa & Panitia \\
\hline
\end{tabular}

Pelatihan pembuatan website menggunakan CMS Joomla pada SMK Bina Putra Mandiri yang menjadi tema pada kegiatan PKM ini mempunya maksud dan tujuan yaitu sebagai penambah wawasan siswa \& siswa SMK Bina Putra Mandiri mengenai CMS Joomla \& meningkatkan kreatifitas siswa \& siswi dalam memilih framework atau CMS yang digunakan dalam membuat suatu website yang akan berguna di kemudian hari. Berikut ini kegiatan PKM yang didokumentasikan: 
Vol. 1. No. 2, Agustus 2021

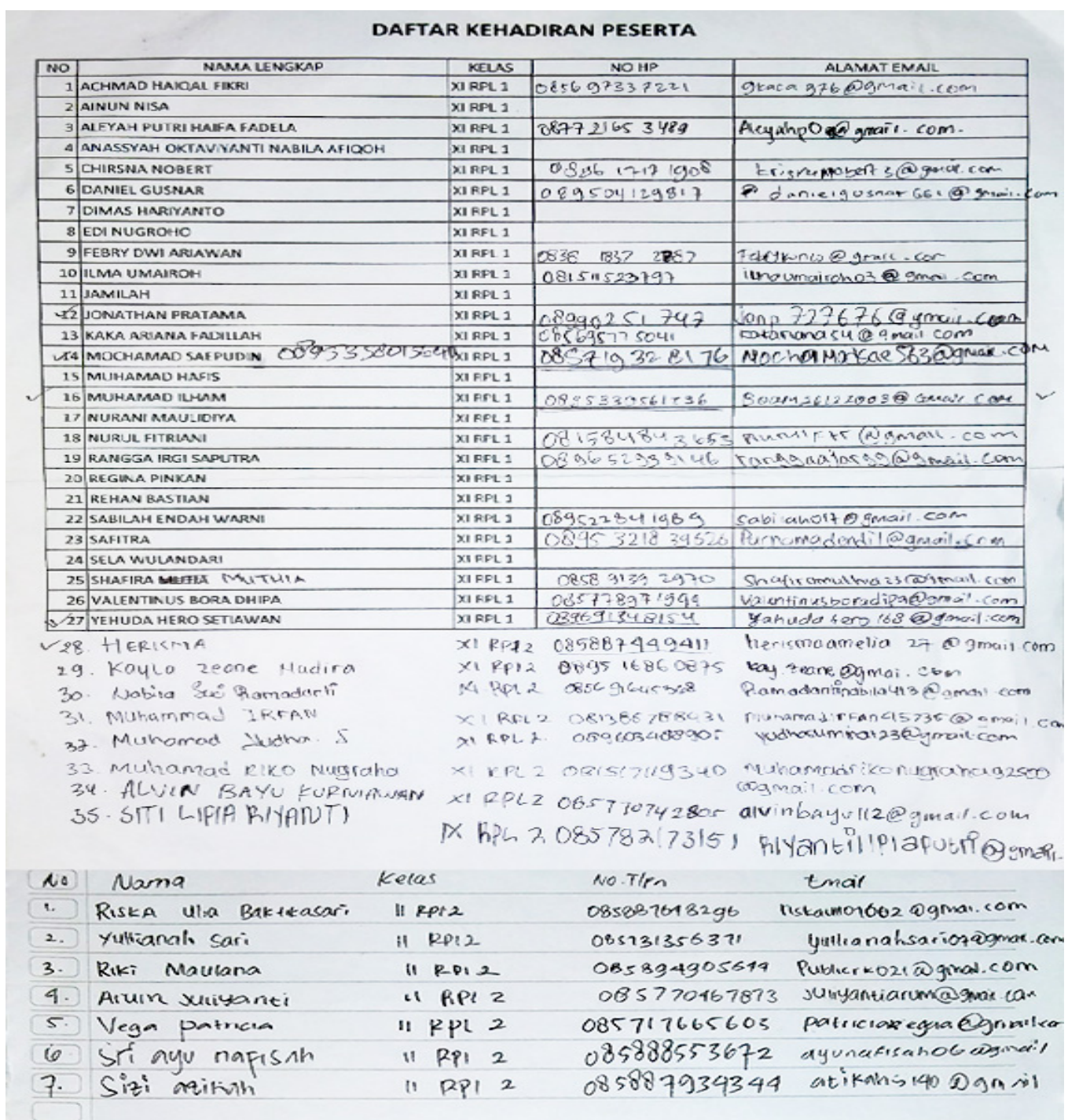

Gambar 1. Daftar Hadir Peserta Pelatihan

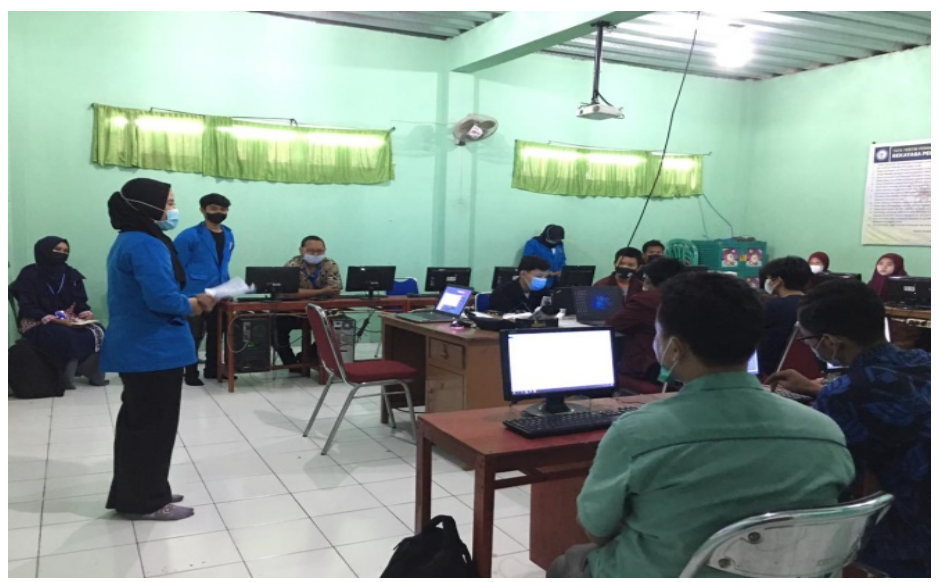

Gambar 2. Pembukaan acara oleh panitia 


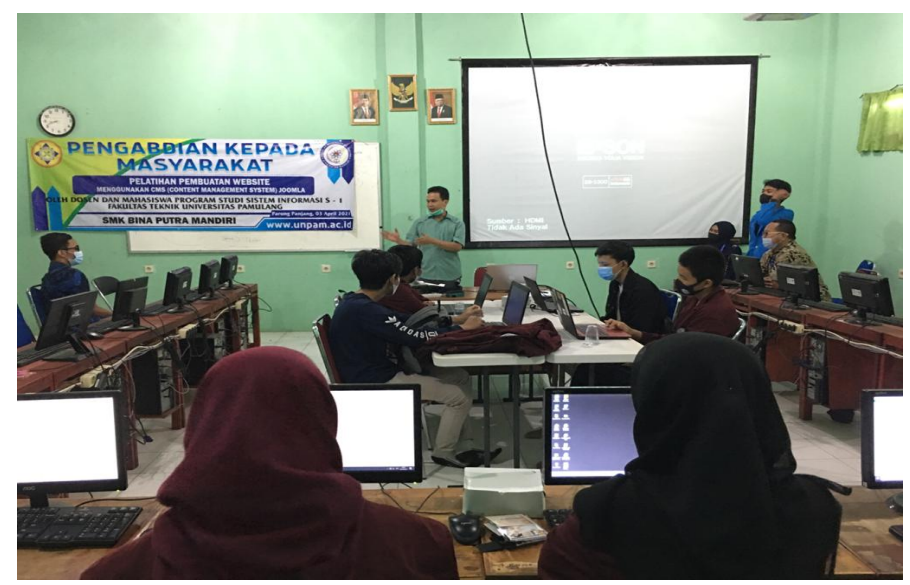

Gambar 3. Sambutan dari pihak sekolah
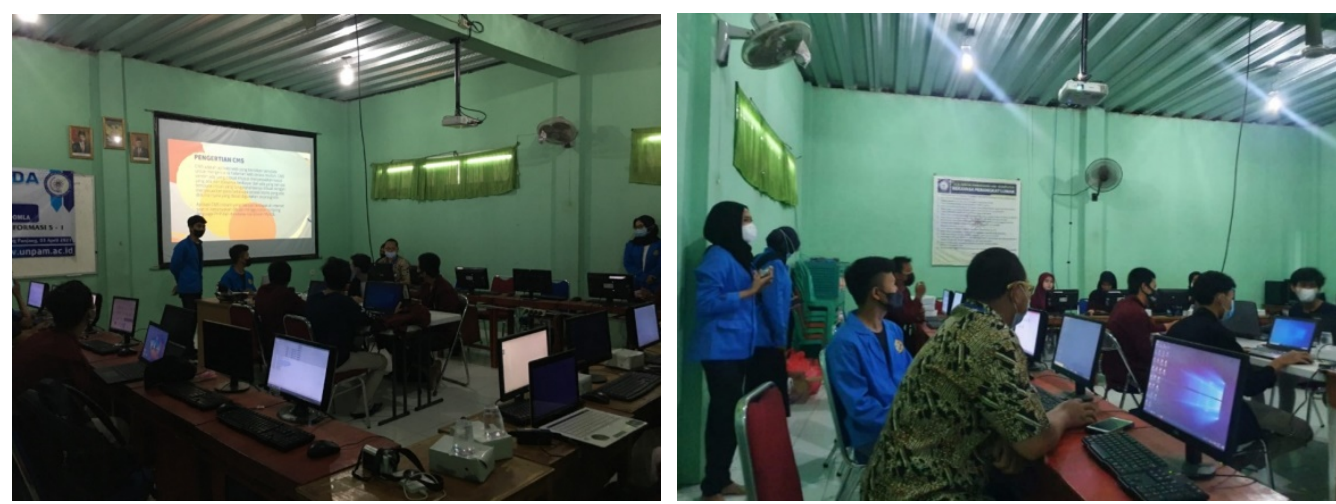

Gambar 4. Dokumentasi saat pemaparan materi
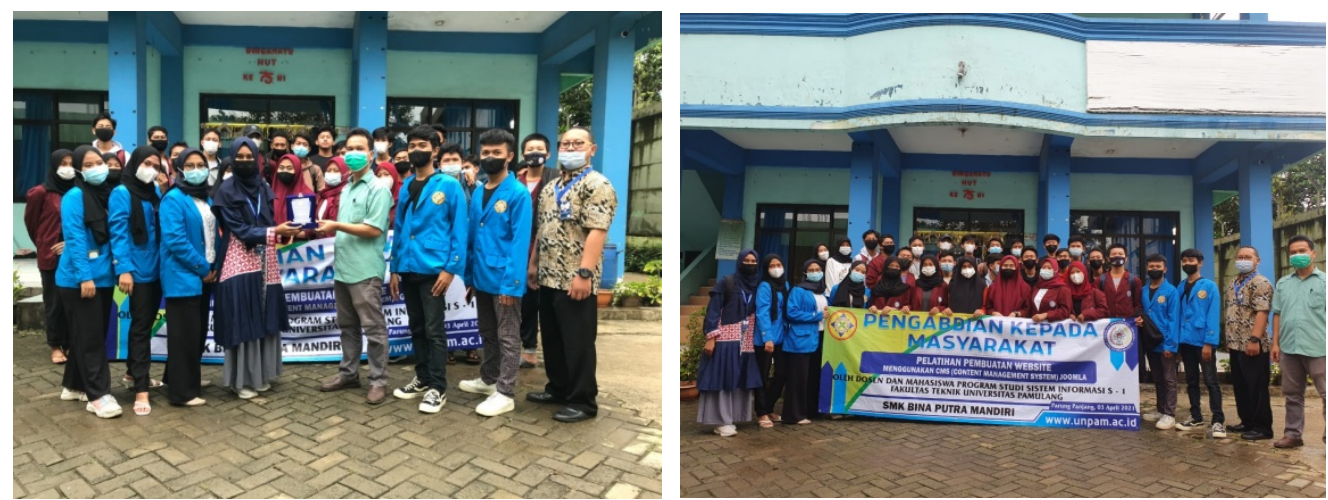

Gambar 5. Dokumentasi penyerahan plakat dan foto bersama

Kegiatan pengabdian kepada masyarakat diharapkan dapat memberikan manfaat terutama pada masyarakat yang dilakukan oleh Tim Fakultas Teknik Sistem Informasi Universitas Pamulang. Kegiatan pengabdian kepada masyarakat dapat menumbuhkan rasa keingintahuan para siswa SMK Bina Putra Mandiri mengenai Content Management System (CMS) sehingga dapat diimplementasikan dalam pembelajaran mengingat kompetensi keahlian siswa yang selaras dengan materi ini. Disamping itu kegiatan ini juga dapat menambah pengetahuan bagi mahasiswa untuk melatih menggunakan ilmu yang telah didapat selama perkuliahan. 


\section{Kesimpulan}

Dari kegiatan Pengabdian Kepada Masyarakat ini dapat diambil kesimpulan bahwa:

1. Dari kandidat pelatihan pembuatan website menggunakan CMS Joomla yang ikut serta yakni siswa dan siswi SMK Bina Putra Mandiri merespon hangat dan mengapresiasi yang mendalam terhadap pelatihan tersebut.

2. Pada pemaparan proses pembuatan website menggunakan CMS Joomla guna mengaktualkan siswa dan siswa SMK Bina Putra Mandiri untuk lebih berkualitas dalam menebarkan pemaparan mengenai komponen pada website CMS Joomla.

3. Tersampaikannya materi pelatihan yang menunjukan adanya respon positif yang diberikan pada pelatihan tersebut.

4. Respon positif yang ditimbulkan oleh peserta dari pelatihan yang dilakukan panitia meliputi siswa dan siswi SMK Bina Putra Mandiri mendapatkan pengetahuan baru yang sebelumnya kesulitan dalam hal membuat website serta terdapat kebanggaan tersendiri oleh peserta pelatihan karena mendapatkan sertifikat keikutsertaan pada kegiatan yang sudah diselenggarakan oleh panitia.

\section{Ucapan Terimakasih}

Penulis dengan segala kerendahan hati menyampaikan ucapan terima kasih kepada Bapak Dede Supriyadi S.Kom, M.Kom selaku Ka. Prodi Program Sarjana Universitas Pamulang. Bapak Ghema Nusa Persada, S. Kom., M. TI sebagai narasumber kegiatan PKM, Ibu Ibu Dwi Ratna Ningtyas, M.Kom selaku Kepala SMK Bina Putra Mandiri serta siswa/i SMK Bina Putra Mandiri terkhusus kompetensi keahlian Rekayasa Perangkat Lunak kelas 11.

\section{Referensi}

Adhi, R., \& Andy, S. (2006). Mastering CMS MAMBO/JOOMLA+ CD. Elex Media Komputindo.

Persada, G. N., \& Wijayanto, S. (2021). Penerapan E-Learning Menggunakan Google Classroom sebagai Sarana Media Belajar di SMK Negeri 2 Tangerang Selatan. 6(1), 34-42.

Rahman, S. (2018). Buku Sakti SEO WordPress dan Joomla. Elex Media Komputindo.

Subariah, R., \& Permana, B. A. (2020). Perancangan Aplikasi Sales Support Untuk Manajemen Pelanggan Berbasis Web. In ESIT (Vol. 15, No. 2, pp. 7-12).

Subariah, R. (2021). PENGUJIAN WHITE BOX PADA APLIKASI DAILY ACTIVITY MONITORING KARYAWAN BERBASIS WEB. In ESIT (Vol. 16, No. 1, pp. 28-33).

Wijayanto s, \& P. G., \& N. (2020). Pengukuran Tingkat Kepuasan Pemanfaatan Google Classroom sebagai Media Pembelajarandi SMK Negeri 2 Tangerang Selatan. Jurnal Ilmu Komputer (JIK)., 3(3), 1-5.

Yuhefizar. (2009). CMM Website Interaktif MCMS Joomla (CMS). Jakarta: PT Elex Media Komputindo Kelompok Gramedia. 